\title{
Nitel Araştırmada Geçerlik ve Güvenirlik: Kuramsal Bir İnceleme Gökhan ARASTAMAN, ${ }^{*}$ İnci ÖZTÜRK FİDAN, ${ }^{* *}$ Tuncer FİDAN***
}

Öz: Bu çalışmanın amacı, nitel araştırma geleneği içinde son dönemlerde sıklıkla ele alınan geçerlik ve güvenirlik ölçütlerine ilişkin tartışmaları incelemektir. Bu amaçla geçerlik ve güvenirlik sorunsalına ilişkin endişeler, konuyla ilgili epistemolojik ve kuramsal kavramsallaştırmalara dayalı olarak ayrıntılı bir şekilde çözümlenmeye çalışılmıştır. Çözümlemeler sonucunda geçerlik ve güvenirlik konusunun son yıllarda giderek önem kazanmaya başladığı ve araştırmacıların konuya yönelik çeşitli yaklaşımlar önerdikleri görülmüştür. Bu önermelerde geçerlik ve güvenirliğin çeşitli şekillerde tanımlanabileceğini ve epistemolojik ve kuramsal farklılıklara dayalı olarak farklı şekilde işlev görebileceğini ortaya koyan görüşlerin yanında, nitel araştırmalarda önceden belirlenmiş ölçütlerin olmasını reddeden, dolayısı ile daha retorik bir yaklaşımla her çalışmanın niteliğinin ayrı değerlendirilmesi gerektiğini vurgulayan görüşlerin olduğu da görülmektedir. Bu çözümlemeye dayalı olarak nitel çalışmalarda geçerlik ve güvenirlik kavramlarının tartışmalı bir konu olduğu ve nitel çalışmaların niteliğini ölçmek için tek bir yolun olmadığı genel sonucuna ulaşılmıştır.

Anahtar Kelimeler: Nitel araştırma, Geçerlik, Güvenirlik, Güven duyulabilirlik

\footnotetext{
*Yrd. Doç.Dr. Gökhan Arastaman, Hacettepe Üniversitesi Eğitim Fakültesi, ORCID: 0000-0002-4713-8643 gokhanarastaman@gmail.com

** Ar. Gör. İnci Öztürk Fidan, Ankara Üniversitesi, Eğitim Bilimleri Fakültesi,ORCID:0000-0001-91772038,iiozturk@yahoo.com *** Dr. Tuncer Fidan, Mehmet Akif Üniversitesi, İç denetçi, ORCID: 0000-00002-9954-1004, tuncerfidan@gmail.com
}

\begin{tabular}{lll}
\hline Gönderim:27.10..2017 & Kabul:28.12.2017 & Yayın:01.02.2018
\end{tabular}




\title{
Validity and Reliability In Qualitative Research: A Theoretical Analysis
}

\begin{abstract}
The purpose of this study is to examine the debates about the validity and reliability criteria that are frequently addressed in the qualitative research tradition. For this purpose, concerns about validity and reliability issue have been analyzed in detail based on epistemological and theoretical conceptualizations. As a result of the analysis, it is seen that the issue of validity and reliability is important and researchers propose various conceptual and theoretical approaches to the subject. In addition to the views suggesting that these propositions regarding validity and reliability issue can be defined in various ways and function differently based on epistemological and theoretical differences. It is also seen that there are views emphasizing that the quality of each study should be assessed separately with a more rhetorical approach because it refuses to have pre-determined criteria in qualitative researches. Based on this analysis, the general conclusion that measuring the quality of qualitative studies is a controversial issue and there is no single way to measure quality has been obtained.
\end{abstract}

Keywords: Qualitative research, Validity, Reliability, Trusthwortiness

\section{Giriş}

18. yüzyıl Avrupasında ortaya çıkan “Aydınlanma Çağı” ile birlikte pozitivizm, optimizim, akıl ve sürekli ilerleme gibi kavramlar başat söylemlere dönüşmüştür. Bütün bilgilere akıl yürütme yoluyla ulaşılabileceğine inanılan bu dönemde rasyonel insanın, titiz bir uslamlama ile örtük gerçekliği açığa çıkarabilecek yeteneğe sahip olduğu düşüncesi egemen olmuştur. Aydınlanma çağı düşünürlerine göre gözlem yoluyla elde edilen verilerin mantıksal süreçlerle işlenmesiyle ulaşılan bilimsel bilgi, cehalet ve batıl inançları ortadan kaldırabilecek 
potansiyele sahipti. Başka bir ifadeyle pozitivizm için gerçeklik mutlaktır, kişilere göre farkl1laşmamaktaydı. Gerçeğe uygun betimlemeler, açık amaçlar, düzgün bir şekilde ölçülmüş nicel sonuçlar, yansızlık ve nesnelliğe yapılan vurgu, gerçekleri ve değerleri birbirlerinden ayıran kuramsal sınamalar gibi özellikler bilimsel araştırmaları diğer sistematik düşünce biçimlerinden ayırmaktaydı. Nicel yöntemler, doğa bilimlerinden sonra zaman içinde sosyal bilimler için de önemli bir kriter haline gelmiştir (Grbich, 2007).

Her alanda yaşanan hızlı değişimle beraber, insanların sosyal ve kültürel yaşantıları ile ilgili sorunlar ve bulundukları çevreyi algılama biçimlerindeki farklılaşmalar ön plana çıktıkça nitel araştırmaya olan ilgi başlamıştır. Güncel yaşamdaki dinamiklerin çeşitlenmesi, her alanda dezavantajlı grupların artması, farklılaşan yaşam deneyimleri ve değişen sosyal ilişkiler ile birlikte, nitel araştırma yöntemleri sosyal bilimlerde kullanılmaya başlamıştır (Merriam, 2009; Glesne, 2011). Kısacası toplumun nicel araştırma sonuçlarına verdiği tepki, nitel araştırmaların ön plana çıkmasında etkili olmuştur. Örneğin her seçim öncesi yapılan kamuoyu yoklamalarının, mevcut durumun yansız bir şekilde tespitinden ziyade algı manipülasyonu olabileceği endişesi gündemden düşmemektedir. B enzer şekilde, işsizlik ve enflasyon oranları her zaman şüpheyle karşılanmaktadır. Zira insanların deneyimleri farklı şeyler anlatmaktadır (Silverman, 2000).

Hem nitel yöntemlerin sosyal araştırmalarda sıklıkla kullanılmaya başlaması hem de son dönemlerde nitel araştırmacılara sunulan kaynakların, kitapların artmasıyla birlikte araştırmalarda kalitenin nasıl sağlanacağı konusunda önemli tartışmalar yapıldığı ve konuyla ilgili endişelerin de arttığı görülmektedir (Roulston, 2010). 20.yüzyılın başlarında sosyal bilimciler bilimde neyin kanıt olarak sayılacağı konusunda bir fikir birliğine varmışlar ve ne tür bilginin geçerli sayılacağını ortaya koymuşlardır. 1970'li yıllarda nitel araştırma reform hareketi adıyla başlayan hareket, sosyal ve kişisel gerçekliğe ait bazı kavramların pozitivist geleneğin kabul ettiği kanıt bulma ve doğrulama yoluyla mümkün olmayacağını öne sürmüştür 
(Schwadt, 2000). Lincoln ve Guba (1986) araştırmacının araştırma bulgularının dikkate değer olduğu konusunda, okuyucularını nasıl ikna etmelidir, sorusunu sorarak bu tartışmayı başlatmıştır. O tarihten bu yana nitel araştırmacıların bu konuda önemli bir anlayış kazandıkları ve iyi bir nitel araştırmanın niteliğine ilişkin ölçütler geliştiren çok sayıda araştırma yapılmıştır (Maxwell, 1992; Creswell, 2007; Denzin ve Lincoln, 2005; Guba ve Lincoln; 2005; Seale, 1999). Bu araştırmalarda, nitel araştırmacıların araştırma sonuçlarının geçerli ve güvenilir olduğunu bir şekilde göstermesi gerektiği fikrinin ön plana çıktığı görülmektedir.

Nitelikli bir araştırma yapmak, araştırmanın bilimsel kabul edilmesi ve kullanıma uygun olması açısından önemlidir. Ancak geçerlik ve güvenirlik konusunda bir ölçüt geliştirmek Smith'in (1990) de belirttiği gibi sosyal ve eğitim araştırmalarının karşı karşıya bulunduğu en zor ve önemli sorunlardan birisidir. Zira nitel araştırmalar için özel ölçütler geliştirme çabalarının yanında bazı yazarlar, nitel araştırma için önceden belirlenmiş ölçütleri tamamen reddetmiştir. Örneğin Sandelowski ve Barroso (2002), ve Hammersley (2007), nitel araştırma yöntemlerinin epistemolojik yelpazesinin tek bir ölçüt setiyle temsil edilemeyecek kadar geniş olduğunu belirterek, evrensel olarak kabul görecek ölçütler geliştirme fikrine karşı çıkmışlardır. Benzer şekilde iyi bir nitel araştırmanın ölçütü nedir sorusuna Lewis (2009); bunun her zaman kişinin bilimsel görüşüne bağlı olduğunu ve bu konudaki tercihlerin de zaman içinde değişebileceğini belirterek ölçüt geliştirme girişiminden uzak durmuştur.

Belirtilen tartışmaların 1şı̆̆ında, kavramsal tarama modelinde desenlenen bu çalışmanın nitel araştırmalarda geçerlik ve güvenirlik konusundaki alanyazına katkı sağlaması ve konuyla ilgili gelecekteki tartışmalar için zemin oluşturması beklenmektedir. Bu kapsamda alanyazında yer alan sınırlı sayıdaki çalışmalardan (Özdemir, 2010; Yıldırım, 2010; Rüzgar, 2016) farklı olarak, nitel araştırma geleneği içinde tartışmalı bir konu olan geçerlik ve güvenirlik kavramlarına ilişkin ölçüt geliştirme çabalarını değerlendirmek ve bu görüşlerden yola çıkarak bir senteze varmak ihtiyacı bu çalışmanın gerekçesini oluşturmaktadır. 
Bu gerekçe ile çalışmanın amacı nitel araştırma geleneği içinde son dönemlerde sıklıkla ele alınan geçerlik ve güvenirlik ölçütlerine ilişkin tartışmaları değerlendirmektir. Bu amaç doğrultusunda nitel araştırmalarda kullanılan farklı geçerlik güvenirlik kavramlaştırmalarına dayanak teşkil eden felsefe okullarının görüşleri tartışılmış, alanyazında en çok kabul gören sosyal kurmac1-yorumcu geleneğin geçerlik ve güvenirlik ölçütleri incelenmiştir. Bu kapsamda, güvenduyulabilirlik kavramı incelenmiştir.

\section{Nitel Araştırma}

Denzin, Lincoln ve Giardina’ya (2006) göre muhafazakar rejimler, kanıta dayalı ve bilimsel temelli tıbbi araştırma modellerinin kullanılmasını zorunlu kılmaktadır. Devletler dünya çapında "iyi" bilim olarak sayılan şeyleri tanımlayarak bilimsel sorgulamayı düzenlemeye çalışmaktadırlar. Örneğin 2002 yılında çıkarılan "Hiçbir Çocuk Geride Kalmasın Yasası” gibi girişimler cinsiyet, ırk, etnisite ya da sınıf tarafından üretilen sosyal farklılaşmaları göz önünde bulundurarak, kamu eğitiminin karmaşık ve dinamik bağlamını çözümlemekten uzak deneysel-nicel modelin tipik örneğidir. Denzin ve arkadaşlarına (2006) göre yorumcu nitel araştırma geleneği pozitivist ya da postpozitivist paradigmayı eleştirmektedir. Nitekim nitel araştırmaya yönelik pozitivist direnç; "pozitif bilim ile yumuşak bilim” arasındaki ayrım olarak bilinen tartışmanın bir sonucudur. Geleneksel yöntemlerden ayrılan nitel araştırma bu geleneğe bir saldırı olarak görülmektedir. Ancak sosyal bilimlerin, fen bilimlerinin hegemonyasından sıyrılıp özerkleşmesi, kendi yöntembilimi ve dilini yaratmasıyla mümkün olabileceği savunulmaktadır (Özdemir, 2010).

Nitel araştırma, sorulara bütüncül bir şekilde yaklaşmayı, başka bir ifadeyle insani gerçekliklerin karmaşık olduğunu kabul etmeyi gerektirmektedir. Bu nedenle araştırma soruları genellikle geniş kapsamlıdır. Örneğin "Yabancı ülkelerdeki kadınların doğum deneyimleri 
nasıldır?" (Sharts-Engel, 1989) gibi bir soru öznel deneyimlerin ortaya çıkarılmasını sağlayan ucu açık bir sorgulamaya imkân tanımaktadır. Zira nitel araştırmanın odağını insan deneyimleri oluşturmaktadır. Bu aynı zamanda öznelliğe veya insani gerçekliğe doğru bir yöneliştir. Kullanılan araştırma stratejileri bu yönelişi yansıtacak şekilde insanların zamanlarını geçirdikleri mekânlarda onlarla sürekli bir temas içinde olmayı gerektirmektedir. İnsan davranışının içinde şekillendiği bağlamların gözden kaçırılmaması için, araştırmacı soyutlanmış, pasif bir izleyiciden ziyade katılımcı bir gözlemci rolünü üstlenmelidir. Bu nedenle, katılımcı gözlem stratejileri ile derinlemesine ve yapılandırılmamış görüşmeler sıklıkla kullanılan stratejiler arasındadır. Üretilen veriler, araştırma konusunu oluşturan durum bağlamı içinde bir olaydan diğerine sürüklenen insanların genellikle öykü şeklindeki betimlemelerini sunmaktadır (Boyd, 2001).

Bu tartışmalar 1şı̆̆ında nitel araştırma; insani deneyimler ve gerçeklikler hakkında geniş kapsamlı sorular yoluyla insanların yaşamlarını anlamamıza yardımcı olabilecek zengin ve betimleyici verilerin üretilmesi şeklinde tanımlanabilir. Buradaki anahtar sözcügün anlayış olduğunu belirtmek mümkündür. Zira nitel araştırma ile kazanılan bu anlayış insanların dünyalarını değiştirebilecek yeni perspektiflere kapı aralayabilmektedir (Boyd, 2001). Bu tanımdan hareketle, ağırlıklı olarak önceden geliştirilmiş bir kuramı sınama amacını taşıyan nicel araştırmadan farklı olarak nitel araştırmanın kuram geliştirme yönünde bir çaba olduğu ifade edilebilir. Zira nitel araştırma genellikle hakkında çok az bilgi olan sorunları keşfetmek amacıyla yürütülmektedir. Nitel araştırmacılar çoğunlukla araştırma konusu olan fenomen hakkında yeterli bilgiye ulaşamazlar. Çoğunlukla ortada bir kuram olmadığından sınayacak bir şey de yoktur (Morse, 1996). Bu noktada Knafl ve Howard (1984) nitel araştırmanın dört temel amacı bulunduğunu belirtmektedir. Bunlar; araç geliştirme (instrumentation), örneklerle açıklama (illustration), duyarlılık kazandırma (sentization) ve kavramlaştırmadır (conceptualization). 
Araç geliştirme amacını gerçekleştirmek için araştırmacı derinlemesine, yapılandırılmamış sorular kullanabilmektedir. Örneğin, Sever ve diğerleri (2016) “Kimiz biz?” şeklindeki yapılandırılmamış bir soruyla farklı lise türlerine devam eden öğrencilerin okullarıyla nasıl ilişkilere sahip olduklarını gözler önüne sermeyi amaçlamıştır. Elde edilen veriler daha sonraki çalışmalarda, bu öğrencilere ilişkin algımızdan ziyade onların deneyimlerinden türetilen kategorilere dayalı ölçme araçlarının geliştirilmesini sağlayabilmektedir (Knafl ve Howard, 1984).

Örneklerle açıklamanın amacı ise deşifre metninden alıntılanan kısa pasajlarla ulaşılan sonuçları anlamlı kılmaktır. Örneğin öğretmen sendikaları hakkındaki bir araştırmada, sendikalar arasındaki ideolojik farklılıklardan kaynaklı bir rekabet kategorisi, pasajlarla desteklenmediği takdirde herhangi bir nicel araştırmanın sonuçlarıyla benzer şekilde sıradan sayısal veya kategorik bir veriye dönüşebilir (Fidan ve Öztürk, 2016).

Benzer şekilde, nitel araştırmalar diğer insanların deneyimlerine ilişkin kavrayış geliştirmemizi sağlamaktadır. Nitel araştırmalar bu kavrayışı diğer insanlara iletebildiği ölçüde duyarlılık kazandırma amacına hizmet edebilmektedir (Knafl ve Howard, 1984). Cressey’in (1953) yıllarca namuslu bir hayat yaşadıktan sonra zimmet suçu işleyen çalışanlarla ilgili araştırmasının bu kişileri suça yönelten faktörler hakkında yarattığı farkındalık, sonraki araştırmacılar ve iş yaşamındaki profesyoneller için paha biçilemez bir ders niteliğindedir.

Son olarak, nitel araştırmalar kavramlaştırma (veya kuram geliştirme) amacıyla da kullanılabilmektedir (Knafl ve Howard, 1984). Her ne kadar küçük, homojen çalışma gruplarıyla elde edilen verilerle geliştirilen kuramlar eleştiri konusu olsa da bu çalışmaların kümelenmesiyle veya veri ve yöntem çeşitlemesiyle çok sayıda vaka ve farklı özellikteki insanları kapsayan kavramlaştırmalara ulaşmak mümkündür (Estabrooks, Field ve Morse, 1994). Örneğin Sobo, Seid ve Gelhard (2006) odak grup görüşmelerinden elde ettikleri verileri kullanarak ailelerin perspektifinden çocuk sağlığı hizmetlerine erişim engellerine ilişkin altı 
kategoriden oluşan kuramsal bir model geliştirebilmiştir. Bu bağlamda nitel araştırmanın, nicel verilerin içinde kaybolan fenomenlerin açığa çıkarılmasını sağlayabileceği söylenebilir (Marshall ve Rossman, 2006).

\section{Nitel Araştırmanın Kökenleri}

Pozitivizme bayrak açan sosyal bilim düşünce okulları, insan davranışının genel yasalar tarafından yönetildiği ve neden-sonuç ilişkileriyle karakterize edildiği düşüncesine (Durkheim, 1985) karşı çıkmıştır. Bu yaklaşımlar toplumsal dünyanın, sadece araştırılan eyleme katılan bireyler tarafından anlaşılabileceğini kabul etmiştir. Başka bir ifadeyle, bireyin etrafındaki dünyayı yorumlamasının anlaşılması, dışarıdan değil; onun bakış açısından bakmakla mümkündür (Balc1, 2013).

Bu yaklaşımın ilk örneklerinden birini Kant'ın Saf Aklın Eleştirisi (1787/1998) adlı eserinde görmek mümkündür. Kant'a göre (1787/1998, s.302-303) dünyayı anlamanın doğrudan gözlem dışında başka yolları da bulunmaktadır ve insanlar bunu her zaman kullanmaktadır. Algı yalnızca duyularla ilgili değildir, duyuların bize söyledikleri hakkındaki yorumlamalarla da ilgilidir. Dünyanın bilgisi sadece deneyimleyerek elde edilmez, deneyimler hakkındaki düşüncelerden doğan anlayış ile elde edilebilir. Kant'ın (1787/1998) başlattığı düşünce silsilesi sosyal kurmacılık(constuctivism)-yorumculuk düşüncesinin temel ilkelerinden birinin doğmasına yol açmıştır: Nesnel gerçekliği onu deneyimleyen, yürüten ve tanımlayan kişiden ayırmak mümkün değildir (Ormston, Spencer, Barnard ve Snape, 2014).

Sosyal kurmacılı̆̆a-yorumculuğa uzanan düşünce silsilesinde etki bırakmış diğer bir ismin de Dilthey (1923/1988) olduğu söylenebilir. Dilthey kavrayışın (verstehen) önemine vurgu yapmaktadır. Sosyal bilim araştırmacıları, insan yaşamının toplumsal, kültürel ve tarihsel özellikleri arasındaki bağlantıları ortaya çıkarmak ve araştırılan eylemin ortaya çıktığı bağlamı yakalayabilmek için “yaşanmış deneyimleri” keşfetmelidir. Bireyler “yaşanmış 
deneyimlerinin" farkında olmayabilirler. Araştırmacının yardımıyla bu deneyimler ortaya çıkarılabilir. Zira insani bilimlerin amacı toplumsal fenomenlerin anlamını kavramaktır (Dilthey ve Betanzos, 1923/1988, s.24; Ponterotto, 2005).

Dilthey'in (1923/1988) düşüncelerinden ziyadesiyle etkilenen Weber (1978) katı bir yorumcu tutum benimsemek yerine, yorumculuk ve pozitivizm arasında bir orta yol bulmaya çalışmıştır. Ona göre maddesel yaşamın analizi önemlidir, ancak insanların yaşamlarını anlayabilmek için yeterli değildir. Bunun yerine araştırmacı, insanların içinde yaşadıkları maddesel koşullar içinde şekillenen sosyal eylemi anlamak için çaba göstermelidir. Doğa bilimlerinde amaç, kanunlara benzer önermeler geliştirmektir. Sosyal bilimlerde ise amaç öznel olarak anlamlı deneyimleri kavramaktır (Weber, 1978).

Ana hatlarıyla ifade edilen bu düşünce silsilesi sosyal kurmac1-yorumcu okulun ortaya çıkmasını sağlamıştır. Bu okula göre toplumsal yaşamı anlamak için yorumlamak en az gözlem yapmak kadar önem arz etmektedir. İlişkili bir hareket olan sosyal kurmacılık bilginin insanlar tarafından karşılıklı etkileşim içinde oluşturulduğunu ileri sürmektedir. Her iki yaklaşım yansız gözlem ve evrensel kanun düşüncesini kabul etmemekte ve deneyimlerini onu yaşayanların gözünden anlamayı savunmaktadır (Ormston ve diğerleri, 2014).

Bu iki yaklaşım özellikle nitel araştırma yöntem ve tekniklerinin gelişmesinde büyük bir ağırlığa sahiptir. Öte yandan, nitel araştırmanın kökenlerini takip ederken benzer nedenlerden dolayı pozitivizme isyan eden, ancak farklı bir yol izleyen başka bir düşünce silsilesi olan eleştirel okuldan da söz etmek gerekir. Bu düşünce silsilesinin temellerini Marx'ın (akt.: Engels, 1996, s.82) "Filozoflar dünyayı, yalnızca, çeşitli şekillerde yorumlamışlardır; oysa sorun onu değiştirmektir" önermesinde bulmak mümkündür. Eleştirel kuram toplumsal statükoyu bozma, başka bir ifadeyle özgürleştirme ve dönüştürme amacını taşımaktadır. Araştırmanın amaçları ve yöntemleri araştırmacının proaktif değerleri tarafından şekillendirilebilir. Kuşkusuz ki, eleştirel kuramın ortaya çıkmasında Marx’tan sonra en büyük 
pay sahibi Frankfurt Üniversitesindeki Toplumsal Araştırmalar Enstitüsüdür (Sever, 2012). Frankfurt okuluna mensup eleştirel kuramcılar arasında Horkheimer, Adorno ve Marcuse yer almaktadır. Bu isimler II. Dünya Savaşı sırasında Nazi Almanya'sından ABD’ye göç etmişler ve buradaki ırk ayrımcılığı gerçeği ile yüz yüze gelmişlerdir (Kincheloe ve McLaren, 2002). $\mathrm{Bu}$ nedenle, eleştirel kuram ırk, toplumsal sınıf ve cinsiyet gibi kısıtlamaları aşmak için bireylerin güçlendirilmeleri gerekliliğine vurgu yapmaktadır. Araştırmacılar güçlerinin farkında olmalı ve toplumsal eylemi yorumlamak ve aydınlatmak için kuramı kullanmalıdır (Creswell, 2007, 27).

Sosyal kurmacı-yorumcu gelenekte yer alan araştırmacılara benzer şekilde, eleştirel araştırmacılar toplumsal-tarihsel bağlamda inşa edilen bir gerçeklik tasavvurunu savunmakta; ancak olayları gerçeklik ve güç ilişkileri temelinde kavramlaştırmaktadırlar. Araştırmalar baskı altındaki grupların özgürleştirilmesi amacıyla yapılmaktadır. Bu araştırmacılar araştırmacıkatılımcı etkileşimine yönelik diyalektik bir tutum benimsemektedir. Bu etkileşim eşitlikçi ve demokratik bir düzenin kurulması için katılımcıları güçlendirmeyi amaçlamaktadır (Ponterotto, 2005).

Pozitivizme duyulan memnuniyetsizlik nedeniyle, 20. Yüzyılda Popper'ın (2002) etkisiyle ortaya çıkan diğer bir düşünce silsilesi de postpozitivizmdir. Pozitivistler nesnel gerçekliğin tam olarak kavranabileceği varsayımını benimserken postpozitivistler nesnel gerçekliğin kusurlu bir şekilde kavranabileceğini kabul etmektedir. Postpozitivizme göre insanların zihinsel mekanizmaları kusurludur ve insan yaşamına ilişkin fenomenler kolaylıkla kontrol edilemezler. $\mathrm{Bu}$ nedenle, gerçekliği tam olarak anlayabilmek mümkün değildir. Pozitivizm ve postpozitivizm arasındaki temel farklılık ilkinin kuramın doğrulanmasını vurgularken ikincinin kuramın yanlışlanmasını vurgulamasıdır (Guba ve Lincoln, 2005; Popper, 2002). Guba ve Lincoln'ün (1994) ifadesiyle “bütün kuğular beyazdır önermesinin 
doğruluğunu bir milyon beyaz kuğu kesin olarak kanıtlayamaz; ancak tek bir siyah kuğu yanlışlayabilir”.

\section{Nitel araştırmalarda Geçerlik ve Güvenirlik}

Nitel araştırmalar, öznelliğin yüksek olması ve geçerlik ve güvenirliğin düşük olması bakımından eleştirilmektedir. Örneğin nitel araştırmanın genel bir sistematiğinin olmadığı ve daha çok belirli bir araştırmacıya bağlı olarak bulgular ürettiğine yönelik eleştiriler bulunmaktadır. $\mathrm{Bu}$ eleştiriler sıklıkla belgelerin ve bulgulara ait raporlandırmanın düşük niteliğe sahip olmasına dayandırılmaktadır. Bilgi edinmenin zor olduğu, fenomenlerle ilgili bütüncül bir bakış açısı sunan nitel araştırmaya yönelik bu eleştirinin adil olmadığı söylenebilir. Nitekim nitel araştırma yöntemleri, insan yaşamının ve sosyal dünyanın anlam ve deneyim boyutlarını anlamaya yöneliktir. Başka bir ifadeyle nitel araştırma yöntemlerinin doğası, istatistiksel veya ampirik hesaplamalara dayanmaz (Brink, 1991).

Uzak doğuda yasadışı horoz dövüşlerini izleyen bir antropolog (Geertz, 2005), öğrenci olmaya atfedilen anlamı betimlemeye çalışan bir eğitim bilimci, bir sohbet odasındaki söylem olaylarını analiz etmeye çalışan bir dilbilimci ile ölümün eşiğindeki hastaların farkındalıklarını inceleyen bir sosyolog arasındaki ortak noktalar aynı zamanda neyin nitel araştırma sayılabileceği sorusunun da yanıtı olabilir. Bu yanıt aynı zamanda nitel araştırmaların geçerliği ve güvenilirliği için de temel bir hareket noktası oluşturabilir. Zira benzer paradigma seçimi nedeniyle farklı disiplinlerdeki farklı çalışmalarda araştırmacı veya katılımcıya biçilen roller benzerlikler taşıyabilir. Bu nedenle araştırmacının, paradigmasının geçerlik ve güvenirlik ölçütü seçiminde büyük bir etkiye sahip olduğunu ifade etmek mümkündür (Creswell ve Miller, 2000). 
Pozitivizm ve postpozitivizme göre bir araştırmanın niteliğini sağlayan şey kesinliktir (rigor). Araştırmanın kesinliğini, bulguların gerçekliğe uygunluğunu ifade eden içsel geçerlik, genellenebilirliğini ifade eden dışsal geçerlik, zaman içinde tutarlı bir şekilde tekrarlanmasını ifade eden güvenirlik ve araştırmacının fenomene mesafeli ve yansız olarak yaklaşmasını ifade eden nesnellik sağlamaktadır (Guba ve Lincoln, 1994). Çeşitleme (triangulation), meslektaş değerlendirmesi (member checking) ve denetim izi (audit trail) ölçütleri pozitivizm ve postpozitivizmin etkisiyle nitel araştırmalarda kullanılan teknikler arasında sayılabilir (Creswell ve Miller, 2000).

Öte yandan, sosyal kurmacılık-yorumculuk gibi felsefi düşünce sistemlerinin etkilerini yansıtan esnek desenleme stratejileri, nitel araştırmalarda pozitivizm ve postpozitivizmin kesinlik varsayımının kullanılmasını güçleştirmektedir (Creswell, 2007). Zira nitel araştırmada katılımcılar veya olaylar üzerinde manipülasyon ve bulgularla ilgili önceden belirlenmiş sınırlamalar yoktur. Araştırma deseninin, durum değiştikçe veya sorun daha iyi anlaşıldıkça yeni sorgulamaların uygulanabilmesine izin verecek şekilde esnek olması gerekmektedir. Katı bir desene hapsolmak yerine yeni keşfetme yolları ortaya çıktıkça bunları takip etmek nitel araştırmanın doğacı niteliklerine daha uygun bir yaklaşımdır (Patton, 2002). Bu nedenle sosyal kurmacılık-yorumculuk paradigmasını benimseyen Guba ve Lincoln (1994) kesinlik kavramı yerine güvenduyulabilirlik (trustworthiness) kavramını önermektedir. Uzun süreli irtibat kurma ve sürekli gözlem sosyal kurmacılık-yorumculuk etkisiyle ortaya çıkan nitelik arttırıcı tekniklere örnek gösterilebilir (Creswell ve Miller, 2000).

Eleştirel kuram ise geçerlik ve güvenirlik konusunda farklı bir yol izlemektedir. Eleştirel kuramcılara göre araştırmanın niteliğini araştırmanın tarihsel konumlanışı sağlamaktadır. Başka bir ifadeyle araştırmacı üzerinde çalışılan durumun toplumsal, siyasal, kültürel, ekonomik, etnik ve cinsiyete ilişkin bağlamını göz önünde bulundurmak zorundadır. Araştırma bilgisizlik ve yanlış anlamaları ortadan kaldırdığı ve mevcut yapının dönüşümü için insanları 
eyleme geçirebildiği (praxis) ölçüde nitelik kazanmaktadır (Guba ve Lincoln, 1994). Örneğin, eleştirel kuramın temsilcilerinden Carr ve Kemnis (2003) Habermas'ın iletişimsel eylem kuramına dayalı olarak nitel araştırmalarda iletişimin niteliğini arttırmaya yönelik ölçütler geliştirmiştir. Creswell ve Miller (2000) yansıtıcı düşünme tekniğini eleştirel kuramın etkisiyle ortaya çıkan nitelik arttırıcı tekniklere örnek olarak göstermektedir.

Görüldügü üzere farklı düşünsel geleneklere mensup çok sayıda nitel araştırmacı nitel çalışmaların niteliğini arttırıcı farklı ölçütler önermiştir. Bu ölçütlerin en sık kullanılanları Tablo 1'de özetlenmiştir.

\section{Tablo 1.}

\section{Alanyazında Önerilen Niteliği Arttırıcı Ölçütler}

Yazar Niteliği arttırıcı ölçütler

\begin{tabular}{|c|c|}
\hline $\begin{array}{l}\text { Guba (1981), Lincoln } \\
\text { ve Guba (1986) }\end{array}$ & $\begin{array}{l}\text { - Güvenduyulabilirlik: İnandırıcılık, aktarılabilirlik, } \\
\text { güvenilebilirlik, onaylanabilirlik. }\end{array}$ \\
\hline $\begin{array}{ll}\text { Carr ve Kemnis } \\
\text { (1986) }\end{array}$ & $\begin{array}{ll}\text { - } & \text { İfadenin gerçekliği, } \\
\text { - } & \text { İfadenin anlaşılabilirliği } \\
\text { - } & \text { Konuşmacının samimiyeti } \\
\text { - } & \text { Konuşma hakkı. }\end{array}$ \\
\hline $\begin{array}{l}\text { Eisenhart ve Hove } \\
(1992) \\
\end{array}$ & $\begin{array}{l}\text { - Araştırma soruları, veri toplama ve analiz teknikleri arasında } \\
\text { - Uyumun sağlanması } \\
\text { - Uygun veri toplama ve analiz yöntemlerinin kullanımı } \\
\text { - Ilgili alanyazınla kiyaslandığında inanılabilir bulgulara } \\
\text { ulaşılması, } \\
\text { - Uygulamada kullanılabilecek değerli sonuçlara ulaşılması, } \\
\text { - Bütün ölçütlerin uyum içinde kullanımı. }\end{array}$ \\
\hline $\begin{array}{l}\text { Sandelowski (1986, } \\
\text { 1993) }\end{array}$ & $\begin{array}{l}\text { - Inandirıcilik, } \\
\text { - Uyarlanabilirlik, } \\
\text { - İzlenebilirlik, } \\
\text { - Onaylanabilirlik, } \\
\text { - } \quad \text { Yaratıcilik, } \\
\text { - Uygun Desenleme }\end{array}$ \\
\hline Maxwell (1992) & $\begin{array}{ll}\text { - } & \text { Betimsel geçerlik, } \\
\text { - } & \text { Yorumlayıcı geçerlik, } \\
\text { - } & \text { Kuramsal geçerlik, } \\
\text { - } & \text { Değerlendirmeci geçerlik, } \\
\text { - } & \text { Genellenebilirlik. }\end{array}$ \\
\hline
\end{tabular}




\begin{tabular}{|c|c|}
\hline Lather (1993) & $\begin{array}{l}\text { - } \quad \text { Alaycı (ironic), } \\
\text { - } \quad \text { Mantık ötesi (paralogical), } \\
\text { - } \quad \text { Kök (rhizomatic), } \\
\text { - } \quad \text { Duysal (voluptuous) geçerlik }\end{array}$ \\
\hline Leininger (1994) & $\begin{array}{ll}\text { - İnandırıcılık } \\
\text { - Onaylanabilirlik, } \\
\text { - Anlamın bağlamsallığı, } \\
\text { - } \quad \text { Tekrarlayan kalıplar, } \\
\text { - Doygunluk, } \\
\text { - } & \text { Aktarılabilirlik. } \\
\end{array}$ \\
\hline Thorne (1997) & $\begin{array}{l}\text { - Yöntembilimsel bütünlük, } \\
\text { - Temsili inandırıcılık, } \\
\text { - Analitik mantık, } \\
\text { - Yorumlamada yetkinlik. }\end{array}$ \\
\hline $\begin{array}{l}\text { Whittemore, Chase ve } \\
\text { Mandle (2001) }\end{array}$ & $\begin{array}{l}\text { - Birincil ölçütler: İnandırıcılık, otantiklik, kritiklik, bütünlük. } \\
\text { • İkincil ölçütler: Açıklık, canlılık, yaratıcılık, tamlık, } \\
\text { uyumluluk. }\end{array}$ \\
\hline
\end{tabular}

Tablo 1 incelendiğinde, nitel araştırmalarda niteliği arttırıcı ölçütlerin araştırma paradigmalarının etkisiyle şekillendiği görülmektedir. Örneğin, Carr ve Kemnis (2003) ile Lather'in (1993) önerdiği ölçütler katı bir şekilde eleştirel kuramı yansıtırken Maxwell'in (1992) genellenebilirlik ölçütü pozitivizmden ödünç alınmıştır. Whittemore, Chase ve Mandle (2001) ise niteliği arttırıcı ölçütleri sentezleyerek genel bir çerçeveye oturtmaya çalışmaktadır. Bununla birlikte, Guba (1981) ile Lincoln ve Guba (1986) tarafından pozitivizmin kesinlik varsayımına paralel olarak önerilen güvenduyulabilirlik (trustworthiness) varsayımının genel olarak kabul gördüğü ifade edilebilir. $\mathrm{Bu}$ nedenle, niteliği arttırıcı ölçüt ve tekniklerin güvenduyulabilirlik kavramı temelinde betimlenmesinin nitel araştırmacıların sıklıkla içine düştükleri kavramsal karmaşayı ortadan kaldırabileceği düşünülmektedir.

\section{Güvenduyulabilirlik (Trustworthiness)}

Araştırmanın güvenduyulabilirliğini inandırıcılık (credibility), aktarılabilirlik (transferability), güvenilebilirlik (dependability) ve onaylanabilirlik (confirmability) ölçütleri 
sağlamaktadır. Inandırıcılık, bulguların gerçeklikle ne düzeyde uyumlu olduğunu ifade etmektedir. Aktarılabilirlik, bulguların diğer bağlamlara ne düzeyde uyarlanabildiği ile ilgilidir. Güvenilebilirlik, aynı bağlamda aynı katılımcılarla aynı bulgulara ulaşılmasını ifade etmektedir. Onaylanabilirlik ise bulgularının araştırmacının değil, katılımcıların deneyim ve düşüncelerinden kaynaklandığını ortaya koymaktır (Shenton, 2004). Guba’ya göre (1981) nitel araştırmaların güvenduyulabilirliği gerçekliğin değerinin yansıtılması, uygulanabilirlik, tutarlık ve yansızlık endişelerinin giderilmesine bağlıdır. Pek tabii ki nitel araştırmaların nicel araştırmalar gibi toplanan verilerin araştırılan fenomeni kesin olarak temsil ettiği gibi bir iddiası yoktur. Bu nedenle gerçeklik değerinden kastedilen doğadaki gerçeklikten ziyade insanların zihinlerindeki çoklu gerçekliğin yansıtılmasıdır. Gerçeklik değerinin yansıtılması bulguların ve yorumların inandırıcılığının sağlanmasıyla mümkün olmaktadır. Çoklu gerçeklik varsayımından hareketle nitel araştırmacılar bütün zaman ve mekânlarda geçerli genellemeler oluşturmak için çaba sarf etmez. Bunun yerine, araştırma sonuçlarının aralarındaki benzerliklere bağlı olarak farklı bağlamlarda uygulanabilirliğini, başka bir ifadeyle aktarılabilirliğini sağlamaya çalışır. Çoklu gerçekliğin ve insanlarla çalışmanın yol açtığı başka bir husus ise nitel araştırmalarda tutarlık kavramının değişmezliği değil kaynağı açıklanabilen değişkenliği ifade etmesidir. $\mathrm{Bu}$ nedenle nitel araştırmalarda tutarlığ güvenilebilirlik kavramıyla betimlemek mümkündür. Bunlara ek olarak, nitel araştırmacının veri toplama aracının kendisi olmasından dolayı nesnellik yükü üretilen verilere yüklenmiştir. Bu noktada nitel araştırmalarda yansızlığın üretilen verilerin onaylanabilirliği ile sağlandığını söylemek mümkündür (Guba, 1981).

İnandırıcılık. Merriam ve Tisdell'e göre (2015) pozitivist paradigmadaki içsel geçerliğin nitel araştırmadaki karşılığı inandırıcılıktır. İçsel geçerlik bulguların gerçeklikle ne kadar uyumlu olduklarıyla ilgilidir. Bununla birlikte, nitel araştırmada gerçek bütüncül, çok boyutlu ve durmaksızın değişmektedir. Başka bir ifadeyle nicel araştırmada olduğu gibi 
keşfedilmeyi bekleyen tek bir sabit ve nesnel fenomen söz konusu değildir. Bu nedenle üretilen veri ile bu verinin kaynağı olan gerçeklik arasında bir eşbiçimliliğin aranması uygun bir geçerlik ölçütü değildir. Nihayetinde katılımcıların perspektiflerinin anlaşılmasının, davranışlarının karmaşıklığının ortaya konmasının ve deneyimleri hakkında bütüncül bir yoruma ulaşılmasının nitel araştırmaların inandırıcılığını sağladığını söylemek mümkündür (Merriam ve Tisdell, 2015). İnandırıcılığın sağlanması için alanyazında bir dizi teknik önerilmiştir. Bu teknikleri şu şekilde özetlemek mümkündür (Guba, 1981; Lincoln ve Guba, 1986; Miles ve Huberman, 1994; Shenton, 2004):

1. İyi bilinen araştırma yöntemlerinin kullanılması. Üzerinde çalışılan kavramlar için daha önce etkililiği kanıtlanmış doğru ve uygulanabilir araçların kullanımı değerlendiriciler ve okuyucular için önemli bir referans noktası oluşturmaktadır (Yin, 2009, s.41). Bu nedenle veri toplama çalışmalarında takip edilen belirli bir soru sırası ve veri analizi yöntemleri gibi belirli işlemler, mümkünse daha önce başarıyla uygulanmış örnekler arasından seçilmelidir (Shenton, 2004). Örneğin Cramer, Liston, Nevin ve Thousand (2010) “ortak öğretmenlik” konulu araştırmalarında, daha evvel Liston (2004) tarafından geliştirilen ve proje ekibi tarafından ön uygulaması yapılmış olan görüşme sorularını kullanmışlardır.

2. Uzun süreli irtibat kurma. Uygulamaya başlamadan evvel araştırma çevresi, mekânları, fenomenleri ve katılımcıları hakkında derinlemesine bilgiye ulaşılması ve araştırma yapılacak örgütlerle ilgili bilgi ve belgelerin incelenerek saha ziyaretleri yapılması, araştırmanın ileriki evrelerinde görüşme ve yorumların çarpıtılmasına neden olabilecek hususların belirlenmesini sağlayabilir (Lincoln ve Guba, 1986; Shenton, 2004). Bununla birlikte, katılımcılarla kurulan uzun süreli irtibat bazı sakıncaları da beraberinde getirmektedir. Araştırmacı, araştırma çevresine çok fazla gömüldüğü zaman profesyonel yargıları etki altında kalabilmektedir (Guba, 1981; Silverman, 2000). 
3. Sürekli gözlem. Araştırma esnasında, alışılmamış özelliklerin yanında genel geçer niteliklerin belirlenmesi araştırmacının aralıksız bir şekilde gözlem yapmasıyla mümkün olmaktadır. Uzun süreli etkileşim araştırmacıların vaka veya bağlamın temel özelliklerini kavramalarını sağlayabilmektedir. Bu husus aynı zamanda ilgisiz özelliklerin ayıklanmasını sağlayabilmektedir. Bu nedenle araştırmacılar uygulama esnasında araştırma konusuna ilişkin yorumlarını destekleyecek ölçüde sahada vakit geçirdiklerini kanıtlayabilmelidir. Araştırmanın seyri hakkında tuttukları notlar veya günlükler, araştırmacıların vaka veya bağlama özgü genel geçer niteliklere ulaşmak için nasıl çaba sarf ettiklerini yansıtmalıdır (Guba, 1981; Lincoln ve Guba, 1986).

4. Katılımcıların rastgele örnekleme yoluyla seçilmesi. Nitel araştırmalarda çoğunlukla amaçlı örnekleme yöntemi kullanılmasına rağmen, rastgele yaklaşım katılımcıların seçimi konusunda araştırmacının önyargılı bir şekilde davrandığı yönündeki ithamları boşa çıkarabilir. Bunun yanında rastgele örnekleme yöntemi bilimsel araştırmanın doğasına daha uygun bir yaklaşımdır. Örneğin çalışma Stake (2005) tarafından betimlenen birden fazla vakayı kapsayan "kolektif vaka çalışması” niteliği taşıyabilir. Bu çalışmalarda sınırlı sayıdaki katılımcıların yalnızca belirli alanlardaki görüşlerinin belirlenmesi amaçlanmaz. Evreni oluşturan bireylerin geneli gibi daha geniş gruplara ilişkin bilginin elde edilmesi için benzerlik, farklılık, çokluk ve çeşitlilik özelliklerini yansıtan çok sayıda katılımcı örnekleme dâhil edilebilir. Ancak öncelikle araştırma öznesi olarak seçilen grubun bütün üyelerinin, o grubun tipik özelliklerini yansittıklarından emin olmak gerekmektedir (Shenton, 2004). Öte yandan, Marshall'a göre (1996) gerçek anlamda rastgele örnekleme yalnızca evrenin genelinin özellikleri bilindiği takdirde mümkün olmaktadır. Üstelik bu özellikler de evren genelinde normal dağılıma sahip olmadığı takdirde çalışma grubunun evreni temsil etmesi beklenmemelidir. Bu nedenle nitel araştırmacı bazı katılımcıların diğerlerine nazaran daha zengin deneyimlere sahip olabileceğini ve araştırmacıya daya ayrıntılı bir anlayış kazandırabileceğini unutmamalıdır (Marshall, 1996). 
5. Çeşitleme. Farklı yöntemlerin, veri kaynaklarının, araştırmacıların ve perspektiflerin, verilerin ve yorumların çapraz kontrollerini yapmak amacıyla bir arada kullanılmasıdır (Denzin ve Lincoln, 2005). Örneğin nitel araştırmaların çoğunluğu için ana veri toplama yöntemleri olan gözlem, odak grup görüşmesi ve bireysel görüşme gibi farklı yöntemlerin kullanımı her birinin yöntembilimsel zayıflıklarını ortadan kaldırabilir. Mümkün olduğu durumlarda belge inceleme yöntemi yoluyla elde edilen veriler görüşme verilerinin doğrulanması amacıyla kullanılabilir. Zira farklı yöntemlerin uyum içinde kullanılması, bu yöntemlerin bireysel sınırlılıklarını dengeleyerek ayrı ayrı sağlayacakları faydaları arttırmaktadır. Çeşitlemenin başka bir türü olan veri çeşitlemesinde farklı katılımcı gruplarından ve farklı çevrelerden toplanacak veriler yardımıyla bireysel deneyim ve yorumlar farklı kaynaklardan doğrulanabilmektedir. Bunun yanında, birden fazla araştırmacıyla çalışıldığı durumlarda araştırmacı çeşitlemesi uygulanmalıdır. Araştırma ekibi gruplara ayrılmalı ve araştırmacıların algı ve yorumları kıyaslanmalıdır. Son olarak, araştırmanın farklı kuramlara dayanması, alternatif açıklama ve yorumların sınanmasını sağlayabilmektedir (Guba, 1981; Shenton, 2004). Çeşitleme son derece etkili bir doğrulama tekniği olarak görülmektedir. Bu nedenle, bazı kuramcılar onu sıradan bir teknikten ziyade alternatif bir nitelik arttırma yaklaşımı olarak kabul etmektedir (Denzin ve Lincoln, 2005).

6. Katılımcı dürüstlüğünü destekleyen taktiklerin kullanımı. Özellikle görüşme yapılmak istenen her bir kişiye projeye katılmayı reddetme imkânı tanınmalıdır. Bu şekilde veri toplama seanslarının yalnızca samimi olarak katkı sağlamak isteyen ve özgür iradesiyle veri sunmaya hazır kişilerle yürütülmesi sağlanabilir. Seansların başlangıcından itibaren katılımcılar açık sözlü olmaları yönünde teşvik edilmelidir. Araştırmacı başlangıç anlarında yakınlık kurmaya çalışmalı ve sorulacak soruların herhangi bir doğru cevabı olmadığını ifade etmelidir. Uygun durumlarda, araştırmacının bağımsız statüsü ayrıca vurgulanmalıdır. Katılımcılara 
istedikleri zaman herhangi bir gerekçe göstermeden çalışmadan çekilebilecekleri açıklanmalıdır (Shenton, 2004).

7. Tekrarlı sorgulamalar. Erken dönem etnografik çalışmalardan itibaren tekrarlı sorgulamalar güçlü bir analiz yöntemi olarak kabul edilmektedir (Thomas ve Nyce, 1998). Zira araştırma konusu fenomen ayrı bir varlık haline dönüşünceye kadar katılımcının deneyimlerine gömülüdür. Fakat kişisel deneyimlerin öznelliği onları önyargı ve içsel çatışmaların etkisine açık kılmaktadır (Ray, 1994). Çelişkilerin, yalanların ve şüpheli verilerin tespiti için araştırmacılar, katılımcı tarafından daha önce gündeme getirilen konulara dönme ve önceki soruları farklı şekillerde ifade ederek eldeki verilerin özüne inme yolunu seçebilirler. Daha fazla şeffaflık sağlayan alternatif bir yaklaşım da araştırmanın sonuç raporunda çelişkilere dikkat çekmek ve bu konuya yol açan muhtemel nedenleri açıklamaktır (Shenton, 2004).

8. Olumsuz durum analizi. Araştırma konusu fenomenin kavranması ve yorumlanması esnasında ortaya çıkan olumsuz durum veya olayların analiz edilmesidir (Lincoln ve Guba, 1986). Araştırmacı öncelikle tema veya kategorileri oluşturmalı, ardından bunlarla uyumlu veya uyumsuz verileri ortaya çıkarmaya çalışmalıdır (Creswell ve Miller, 2000). Eğer çalışma sınıflandırma geliştirmeyi içeriyorsa, araştırmacı başlangıçtaki kategorileri tamamlar tamamlamaz toplanan verileri yeniden değerlendirebilir. Bazı kategoriler yalnızca birer olayı içerebilir. Buradaki amaç yine de kategorilerin çalışma konusu fenomene ilişkin bütün olayların nedenlerini açıklayıp açıklayamadıklarını doğrulamaktır (Shenton, 2004). Bu tekniğin araştırmacının perspektifine dayalı olduğu için sosyal kurmacı-yorumcu paradigmanın etkisini taşıdığı ifade edilebilir (Creswell ve Miller, 2000).

9. Kısa aralıklı toplantılar. Araştırmacı ile araştırma grubu yöneticisinin veya danışmanının sık sık bir araya gelmeleri, verilere ilişkin anlayış ve yorumları derinleştirerek araştırmacının vizyonunu genişletebilir. Zira toplantıya katılan diğer insanlar deneyimlerini ve algılarını tartışmalar yoluyla araştırmacıya aktarabilirler. Bu tür işbirlikçi oturumlar araştırmacı 
tarafından alternatif yaklaşımları tartışmak amacıyla kullanılabilir. Yönetici konumundakiler ise çalışma akışı içinde gözlenen hatalara dikkat çekebilirler. Bu toplantılar ayrıca araştırmacılar için olgunlaşmamış düşünce ve yorumlarını test edebilecekleri bir platform olarak işlev gösterebilir. Diğer insanların eleştirilerini dinlemek araştırmacının önyargılı ve imtiyazlı davrandığı hususları fark etmesini sağlayabilir (Lam ve Hung, 2013; Shenton, 2004).

10. Meslektaş değerlendirmesi. Araştırmacının dürüstlüğünü korumak, hipotezlerini geliştirmek ve araştırma desenini şekillendirmek için kendisini çalışmayla ilgisi bulunmayan bir meslektaşının denetimine açması ve ondan destek almasıdır (Lincoln ve Guba, 1986). Araştırmacılar düzenli olarak araştırma çevresinden ayrılarak tez izleme komitesi üyeleri, diğer öğretim elemanları ve kongre katılımcıları gibi çalışmalarını değerlendirebilecek uzman kişilerle iletişime geçmelidir. Bu şekilde elde edilen dönütler araştırmacıya farklı perspektifler kazandırabilir (Guba, 1981). Zira bu kişiler şeytanın avukatlığını yaparak araştırmacı tarafından geliştirilen varsayımlara meydan okuyabilirler ve araştırmacıyı bir sonraki yöntembilimsel aşamaya geçmesi için zorlayabilirler. Ayrıca kullanılan yöntem ve araştırmacının yorumları hakkında zor sorular yönelterek hataların fark edilmesini sağlayabilirler (Creswell ve Miller, 2000).

11. Araştırmacının yansıtıcı yorumları. Yansıtıcı yorumlama, nitel araştırma kelime dağarcı̆̆ında özfarkındalığı, siyasal/kültürel bilinçliliği ve kişinin kendi perspektifine sahip olduğunu ifade etmesinin bir yolu olarak girmiştir. Yansıtıcı yorumlama, bir taraftan veri toplama seansları devam ederken araştırmacının "neyi biliyorum" ve "onu nasıl biliyorum" şeklinde sürekli sorgulamalar yapmasını gerektirmektedir. Yansıtıcı yorumlama nitel araştırmacıya katılımcıların ve raporlama yaptığı kişilerin perspektifleri yanında kendi perspektifinin kültürel, siyasal, toplumsal, ideolojik ve dilbilimsel kökenleri hakkında dikkatli ve bilinçli olması gerektiğini hatırlatmaktadır (Patton, 2002). Araştırmada yansıtıcı yorum; araştırmacının kendisi, araştırma süreci ve geliştirdiği açıklamalar hakkında derinlemesine 
düşünmesini kapsamaktadır. Bu doğrultuda, araştırma sürecinde etkili olan güç ilişsilerinin ve politikanın eleştirel bir şekilde sınanması gerekmektedir. $\mathrm{Bu}$ şekilde veri toplama ve yorumlama sürecinde araştırmacının hesapverebilirliği sağlanabilmektedir. Zira araştırma süreci ve içerik arasındaki sınır belirsizleştikçe, yansıtıcı yorumlama araştırılan fenomen hakkında daha karmaşık ve incelikli bir kavrayış oluşturarak araştırmayı derinleştirmektedir (Sultana, 2007). Ayrıca araştırmacı, raporlama aşamasında sunulan sonuçlar ve tartışmaların araştırmacının yansıtıcı yorumlarıyla şekillenmiş yöntemlere dayalı olarak elde edildiği yönünde bilgi sunmalıdır (Shenton, 2004).

12. Araştırmacının özgeçmişi, nitelikleri ve deneyimleri. Nitel araştırmada ana veri toplama ve analiz aracı olmasından dolayı araştırmacının güvenilirliği, inandırıcılığı sağlamada önemli bir etkendir (Patton, 2002). Zira hakemlerin veya okuyucunun araştırmaciya güven duyması uygulanan işlemlerin yeterliliğiyle eşit oranda öneme sahiptir. Araştırmacının geçmiş deneyimleri, ilgi duyduğu araştırma konuları, eğitimi ve kişisel özellikleri gibi etkenlerin araştırılan fenomenle uyumluluğu hakemlerin ve okuyucunun analizlere ve yorumlara inanmasını kolaylaştırabilir (Shipman, 2015). Bunun yanında varsa araştırmaya mali kaynak sağlayan kurumların belirtilmesi ve araştırmanın yapılmasına imkân tanıyan resmi onaylardan bahsedilmesi hakemlerin ve okuyucuların etik kaygılarının giderilmesini sağlayabilmektedir (Shenton, 2004).

13. Katılımcı kontrolü. İnandırıcılığı sağlamada en önemli ölçüt olarak görülebilir. Zira katılımcı kontrolü verileri ve yorumları doğrudan katılımcılar yoluyla sınama imkânı tanımaktadır. Verilerin doğruluğuna ilişkin kontroller veri toplama görüşmelerinin yapıldığı mahallerde sıcağı sıcağına yapılabileceği gibi veri toplama evresinin sonunda da yapılabilir (Guba, 1981). Buradaki amaç katılımcıların yazılı olarak kaydedilen sözleri ile söylemeyi kastettikleri şeyler arasında uyum olup olmadığını belirlemektir. Kayıt cihazı kullanıldığı durumlarda ise, en azından katılımcıların söylediklerinin doğru bir şsekilde kaydedilip 
kaydedilmediği belirlenmelidir. Bu konudaki en yaygın strateji bulguların katılımcılardan oluşan odak grup tarafından gözden geçirilmesidir. Bunun yanında araştırmacı katılımcılardan ham verilere göz atmalarını isteyebilir. Katılımcılardan tema veya kategorilerin anlam ifade edip etmedikleri, yeterli kanıtlara dayanıp dayanmadıkları ve gerçeğe uygun olup olmadıkları hakkında görüş bildirmeleri istenebilir (Creswell, 2009).

14. Kodlayıcılar arası güvenilirlik. Miles ve Huberman'a göre (1994) iki araştırmacı aynı veri setini kullanarak kodlama yaptığı takdirde tanımlar daha keskin hale gelmektedir. Bu şekilde kodlamaların ne anlama geldiği ve hangi veri parçasının hangi koda ait olduğu hakkında ortak vizyona ulaşmak mümkündür. Kodlayıcıların aynı veri parçaları için benzer kodlar kullanıp kullanmadıkları bu tekniğin temel noktasıdır. Uzlaşmazlıklar ise tanımların genişletilmesi veya düzeltilmesi gerektiğini göstermektedir. Üzerinde uzlaşılan kod sayısının toplam uzlaşılan ve uzlaşılamayan kod sayısına bölünmesiyle kodlayıcılar arası güvenilirlik oranı hesaplanabilir. Başlangıçta kodlayıcılar arası güvenilirliğin \% 70’ten daha yüksek olması beklenmez. Ancak bu oranın \% 80'e yakın olması, hatta verilerin büyüklüğüne göre \% 90'dan fazla olması önerilmektedir (Miles ve Huberman, 1994). Kodlayıcılar arası güvenilirlikle ilgili başka bir teknik de Cohen’in kappa (k) katsayısıdır. Kappa istatistiği şansa dayalı uzlaşmalar çıkarıldıktan sonra geriye kalan uzlaşmaların oranını temsil etmektedir. Kappa istatistiği 0 ile 1 arası değer almaktadır. Genellikle .40 ve üzeri değerlerin kabul edilebilir uzlaşma gücünü ifade ettiği belirtilmektedir (Wynd, Schmidt ve Schaefer, 2003). Bu tekniklerin pozitivist ve postpozitivist paradigmanın kesinlik (rigor) kavramının doğasına daha uygun olduklarını ileri sürmek mümkündür. Bu nedenle Guba (1981), Lincoln ve Guba (1986) ve Shenton (2004) tarafindan önerilmemektedir.

15. Fenomenin ayrıntılı bir şekilde betimlenmesi. Bu alanda yapılacak ayrıntılı tanımlamalar, çalışma konusunu oluşturan vakaları ve bir düzeye kadar onları çevreleyen bağlamları aktarmasından dolayı inandırıcılığı sağlamada önemli bir koşuldur. Bu şekilde 
okuyucuya, tanımlanan kategorilerin ne derecede gerçek durumla uyum içinde olduğunu değerlendirme şansı tanınmış olur (Shenton, 2004). Lincoln ve Guba (1986) ise ayrıntılı betimlemeleri aktarılabilirlik ölçütünün temel teknikleri arasında zikretmektedir.

16. Önceki araştırma bulgularıyla karşılaştırma. Araştırma sonuçlarının geçmişteki çalışma sonuçlarıyla ne derece uyumlu olduğunun değerlendirilmesidir. Araştırmacının, bulgularını alanyazındaki mevcut bulgularla ilişkilendirme yeteneği nitel araştırmaları değerlendirmenin temel ölçütleri arasında sayılabilir (Silverman, 2000). Zira araştırma bulguları mevcut kuramsal veya uygulamaya ilişkin bilgi ile kıyaslanmaktadır (Eisenhart ve Howe, 1992). Bu bağlamda, aynı veya benzer çevre ve konularda yürütülmüş önceki çalışmalar paha biçilmez kaynaklar olarak görülebilir (Silverman, 2000).

Inandırıcılık başlığı altında alanyazındaki belli başlı inandırıcılığı sağlama teknikleri tartışılmıştır. Ancak nitel araştırmanın dinamik doğası ve her geçen gün yeni nitel araştırma ve veri analizi tekniklerinin yaygınlık kazanması nedeniyle yeni tekniklerin ortaya çıkabileceği unutulmamalıdır. Örneğin Whittemore, Chase ve Mandle (2001) deşifrelerin talep eden kişilere sunulması ve NVivo, MAXQDA gibi bilgisayar programlarının kullanımını da etkili inandırıcılık teknikleri arasında zikretmektedir.

\section{Aktarılabilirlik (Transferability)}

Pozitivizme göre araştırmanın dışsal geçerliği bulguların genellenebilirliğine bağlıdır. Öte yandan sosyal kurmacı-yorumcu gelenek genellenebilirlikten kaçınmaktadır. Zira neredeyse bütün toplumsal/davranışsal fenomenler bağlamsaldır (Guba, 1981). Bu noktada, Lincoln ve Guba (1986) genellenebilirlik yerine aktarılabilirlik ölçütünü önermektedir. Aktarılabilirlik; daha evvel tamamlanmış bir araştırmanın belirli bulgularının anlam ve çıkarımları korumak kaydıyla benzer bağlam veya durumlara ne derecede uyarlanabildiğiyle ilgilidir. Bulguların aktarılabilir olup olmadığının belirlenmesi, araştırmaya etki eden bağlamsal 
faktörlerin ve örneklem seçiminde izlenen yöntemlerin eksiksiz bir şekilde betimlenmesiyle mümkündür (Guba, 1981; Leininger, 1994). Shenton (2004) aktarım yapmadan önce (a) çalışmaya dâhil edilen örgütlerin sayısı ve yerleri, (b) veri sağlayan insanlarla ilgili sınırlılıklar, (c) saha çalışmasına dâhil olan kişi sayısı, (ç) kullanılan veri toplama yöntemleri, (d) veri toplama oturumlarının sayısı ve süresi, (e) veri toplama işleminden sonra geçen zaman gibi bilgilerin göz önünde bulundurulması gerektiğini ifade etmektedir.

\section{Güvenilebilirlik (Dependability)}

Guba (1981) pozitivizmin güvenirlik ölçütüne karşılık nitel araştırmalarda güvenilebilirlik ölçütünü önermektedir. Güvenilebilirlik ölçütü araştırmanın bulguları ve yorumlarının tutarlı bir sürecin ürünü olmasını ifade etmektedir. Başka bir ifadeyle bulguların elde edildiği sürecin mümkün olduğu ölçüde açık ve tekrarlanabilir olması gerekmektedir. Bu husus nitel araştırma desenlerinin esnekliğiyle yakından ilgilidir. Zira nitel araştırma desenleri önceden belirlenmiş katı sınırlamalar içinde tasarlanmazlar. Aksine araştırma süreci olgunlaştıkça belirginleşen ve saha koşullarına göre şekillendirilebilen esnek bir tasarıma sahiptir. Nitel araştırmalarda güvenilebilirlik, belirmekte olan araştırma deseninin dikkatle izlenmesini ve denetim izi -audit trail- (Lincoln ve Guba, 1986) tekniğinin kullanımı ile sağlanabilmektedir.

Denetim izi, araştırma etkinliklerinin ve süreçlerinin; veri toplama ve analiz çalışmaları üzerindeki etkilerin; belirmekte olan temaların, kategorilerin veya modellerin; analiz ve yorumlama sürecinin seyrinin ayrıntılı bir kronolojisidir (Morrow, 2005). Ardından, denetim izine ilişkin raporların araştırmayla ilgisi olmayan bir uzman tarafından incelenmesi gerekmektedir. Uzmanın inceleme neticesinde sürecin geneli hakkında ulaştığı sonuç, güvenilebilirlik yargısını oluşturmaktadır (Lincoln ve Guba, 1986). Benzer şekilde Shenton 
(2004) gelecekteki araştırmacıların çalışmayı tekrarlayabilmesine imkân tanınması amacıyla araştırmayı oluşturan süreçlerin ayrıntılı bir şekilde raporlaştırılması gerektiğini belirtmektedir. Denetim izi tekniğinin yanında Guba (1981) odak grup görüşmesi ve bireysel görüşme gibi “örtüşen yöntemlerin” kullanımını ve iki ayrı araştırma ekibinin veri setini eşit oranda paylaşarak analiz ettikleri ve karşılaştırmalar yaptıkları adım adım tekrarlama (stepwise replication) tekniğini önermektedir.

\section{Onaylanabilirlik (Confirmability)}

Guba (1981) ile Lincoln ve Guba (1986) tarafından pozitivizmin nesnellik ölçütü karşılığında geliştirilen bir ölçüttür. Ancak nesnellikten farklı olarak nesnelliğin hiçbir zaman tam olarak sağlanamayacağı kabulüne dayanmaktadır. Onaylanabilirlik bulguların araştırmacının inançları, arzuları ve önyargılarından ziyade mümkün olduğu kadar araştırılan fenomeni yansıtmasıyla ilgili bir ölçüttür. Bu yaklaşıma göre bulguların bütünlüğü toplanan veride yatmaktadır (Morrow, 2005). Bu noktada bulgularının araştırmacının özellikleri ve seçimlerinden değil de katılımcıların deneyim ve düşüncelerinden kaynaklandığı güvencesini vermek için bazı tekniklerin kullanılması önerilmektedir. Örneğin Guba, (1981) ile Lincoln ve Guba (1986) çeşitleme, yansıtıcı düşünme ve denetim izi tekniklerinin onaylanabilirlik ölçütünün karşılanmasını sağlayabileceğini ifade etmektedir. Farklı perspektiflerden farklı yöntemler kullanılarak elde edilen veriler araştırmacının analiz sırasında bazı temaları özellikle öne çıkarmasına engel olabilir. Ayrıca farklı araştırmacılarla birlikte çalışmak kişisel eğilimleri dengeleyebilir. Yansıtıcı düşünme ise araştırmacının iç dünyasını gözlemleyerek ve kaydederek düşüncelerindeki ve eğilimlerindeki değişimlerin farkına varmasını sağlayabilir. Denetim izi ve dış uzman denetimi her bir yorumun gerçekten veri setine dayandığını doğrulayabilir. Ancak unutmamak gerekir ki denetim izi tekniğinin güvenilebilirlik ölçütündeki odağı araştırma süreci 
iken onaylanabilirlik ölçütündeki odağı ürün, başka bir ifadeyle veri ve yorumlardır (Guba, 1981; Lincoln ve Guba, 1986). Bu tekniklerin yanında Leininger (1994) periyodik katılımc1 kontrolü ve geribildirim seanslarıyla veri ve yorumların doğrudan katılımcılar tarafından onaylanmasının sağlanabileceğini ifade etmektedir.

İnsan deneyimlerini ilgilendiren klinik çalışmalar, politika analizi, eylem araştırması ve nitel araştırma yöntemlerinde gerçek, inandırıcılık, güvenilebilirlik ve doğrulanabilirlik gibi nitel araştırmada niteliği artırıcı ölçütler araştırmacılar için zorlu ancak yorumlarının doğruluğu için de hayati öneme sahip bir tartışma alanıdır. Tüm bu doğrulama stratejileri, karşılıklı etkileşim içinde araştırma süreci ve sonuçları hakkında nicel araştırmalardaki kesinliğe benzer bir güvence sağlayarak geçerlik ve güvenirliği inşa etmektedir. Bilim insanının insani deneyimleri gözle görünür ve dolayısıyla denetlenebilir yapan biri olarak görülmesinden dolayı, nitel araştırmalarda geçerlik ve güvenirlik konusu okuyucuları ikna etme çabası olan güvenduyulabilirlik ile ilişkilendirilmektedir (Altheide ve Johnson, 2011).

\section{Tartışma ve Sonuç}

Bu çalışmada nitel araştırmalar için geçerlik ve güvenirlik konusu, alanyazında var olan önermelere dayalı olarak tartışılmış, konu pozitivist ve yorumsamacı eleştiriler bağlamında konumlandırılmaya çalışılmıştır. Bu amaçla öncelikle nitel paradigmanın epistemolojik gelişim aşamaları tartışılmış daha sonra tarihsel olarak kökenleri irdelenmiştir. Çalışmanın ana gövdesini oluşturan geçerlik ve güvenirlik ölçütleri ise Guba ve Lincoln’un (1981) nitel araştırmalarda niteliği artırıcı yöntemler ekseninde incelenmiş, kronolojik olarak konuya katkı sağlayan yazarların görüşlerine göre tartışılmıştır.

Nitel araştırma alanyazını incelendiğinde geçerlik ve güvenirlik konusunun önem kazandığı ve araştırmacıların konuya yönelik çeşitli kavramsal ve kuramsal yaklaşımlar önerdikleri görülmektedir (Cho ve Trent, 2006,; Denzin ve Lincoln, 2005; Guba ve Lincoln, 
1994; Maxwell, 1992). Nitel araştırmalarda hangi ölçütlerin bulunması gerektiğini araştıran ve çeşitli sınıflandırmalar yapan bu araştırmalara göre nitel araştırmalardaki geçerlik ve güvenirlik stratejileri, geleneksel veya nicel araştırma yöntemlerindeki gibi tanımlanıp uygulanabilir. $\mathrm{Bu}$ çalışmaların içinde en çok atıf alan ve başvuru kaynağı olan eser Lincoln ve Guba'nın (1985) "Doğal İnceleme" isimli eseri olmuştur. Yazarlar pozitivist paradigmanın kavramları olan geçerlik ve güvenirlik kavramı yerine güvenduyulabilirlik kavramını kullanmışlardır.

Lincoln ve Guba ile başlayan bu nitelik ölçütleri geliştirme çabaları bazı yazarlar tarafından kabul görmemiş, önceden belirlenmiş ölçütlerin olması reddedilmiştir (Hammersley ve Atkinson, 2007; Silverman, 2006; Silverman ve Marvasti, 2008). Bu gruptakilere göre geçerlik ve güvenirliğe ilişkin genellenebilir tek tanım yapmak veya operasyonel ölçütler koymaya çalışmak doğru değildir. Örneğin Sandelowski ve Barroso'nun (2002) da belirttiği gibi nitel yöntemlerde epistemolojik çeşitlilik tek bir ölçüt ile temsil edilemeyecek kadar geniştir ve bu yüzden nitel araştırmalar için genel ölçütler aramaktan uzak durmak gerekir. Bunun yerine daha retorik bir yaklaşımla her çalışmanın niteliğinin ayrı değerlendirilmesi gerektiği önerilmektedir. Buradan hareketle nitel araştırmaların niteliğinin “öngörülen formüller” izlenerek belirlenemeyeceği, dolayısı ile iyi bir nitel araştırmanın, bilimsel dünya görüşüne bağlı olduğu ve bu tercihlerin de zaman içinde değişebileceği sonucuna varılabilir. Nitel yöntemlerin önemli ve bağımsız araçlar olması, gerçek yaşam gerçekliğine, gerçek yaşam deneyimlerinden uzak kalmadan yaklaşılması ile mümkündür.

Tüm bu tartışmalar ışığında aşağıdaki genel sonuç ve değerlendirmelere ulaşmak mümkündür. Nitel araştırmalarda niteliğin ölçülmesinin tartışmalı bir konu olmakla beraber nitel araştırmalarda kesin bir nitelik arttırıcı ölçüt belirlemenin mümkün olmadığı görülmektedir. Araştırmanın katılımcıların zihinlerindeki farklı gerçeklikleri doğru ve adil bir şekilde yansıtma, başka bir ifadeyle araştırmanın meşruluğu konusunda okuyucuyu ikna etme çabasının geçerlik ve güvenirlik tartışmalarının merkezinde yer aldığı görülmektedir. Nitel 
araştırmanın esnek ve dinamik nitelikleri ile nitel araştırmalara yön veren farklı paradigmaların zaman içindeki değişimleri farklı geçerlik ve güvenirlik ölçütlerinin geliştirilmesine yol açmıştır. Yine de bu husus nitel araştırma sonuçlarının geçerlik ve güvenirliği konusunda şüpheci bir yaklaşıma yol açmamalıdır. Zira farklı zihinsel gerçekliklerden doğru bilgiye ulaşılamayacağı, ulaşılsa dahi aktarılamayacağı yönünde epistemolojik bir sav nicel araştırmalarda yaşanan tıkanıklık karşısında nitel araştırmacıların giriştiği meşru yöntem ve ölçüt geliştirme çabalarının değersizleşmesine yol açabilir. Bu noktadan hareketle, nitel araştırmacıların hangi geçerlik ve güvenirlik ölçütlerini kullanmaları gerektiği hususunun seçilen araştırma paradigmasına uygun bir şekilde belirlenmesi gerektiği ifade edilebilir. Başka bir ifadeyle eleştirel kuram perspektifinden yürütülen bir araştırmada sosyal kurmac1-yorumcu paradigmanın geçerlik güvenirlik ölçütlerinin güvenduyulabilirliği sağlamada etkili olamayacağı ileri sürülebilir. Bunun yanında, seçilen geçerlik güvenirlik ölçütlerinin farklı gerçekliklerin adil ve eksiksiz bir şekilde araştırma bulgularına yansıtılmasını sağladığı hususunda okuyucuyu ikna etmesi gerekmektedir.

\section{MAKALENIN BİLIMDEKİ YERİ}

Eğitim Yönetimi Anabilim Dalı

\section{MAKALENIN BİLIMDEKİ ÖZGÜNLÜĞ̈̈}

Hem nitel yöntemlerin sosyal araştırmalarda sıklıkla kullanılmaya başlaması hem de son dönemlerde nitel araştırmacılara sunulan kaynakların, kitapların artmasıyla birlikte araştırmalarda kalitenin nasıl sağlanacağı konusunda önemli tartışmalar yapıldığı ve konuyla ilgili endişelerin de arttığı görülmektedir. Nitelikli bir araştırma yapmak, araştırmanın bilimsel kabul edilmesi ve kullanıma uygun olması açısından önemlidir. Ancak geçerlik ve güvenirlik konusunda bir ölçüt geliştirmek sosyal ve eğitim araştırmalarının karşı karşıya bulunduğu en zor ve önemli sorunlardan birisidir.. Bu kapsamda alanyazında yer alan sınırlı sayıdaki 
çalışmalardan farklı olarak, nitel araştırma geleneği içinde tartışmalı bir konu olan geçerlik ve güvenirlik kavramlarına ilişkin ölçüt geliştirme çabalarını değerlendirmek ve bu görüşlerden yola çıkarak bir senteze varmak ihtiyacı bu çalışmanın gerekçesini oluşturmaktadır. Bu çalışmanın nitel araştırmalarda geçerlik ve güvenirlik konusundaki alanyazına katkı sağlaması ve konuyla ilgili gelecekteki tartışmalar için zemin oluşturması beklenmektedir.

\section{Kaynaklar}

Altheide, D. L., \& Johnson, J. M. (2011). Reflections on interpretive adequacy in qualitative research. In. N. K. Denzin ve Y. S. Lincoln (Ed.). The Sage Handbook of Qualitative Research (Forth Edition). (s. 581-594). Thousands Oaks, CA: SAGE Publications, Inc.

Balc1, A. (2013). Sosyal Bilimlerde Araştırma: Yöntem, Teknik ve İlkeler (Genişletilmiş 10. Bask1). Ankara: Pegem Akademi.

Brink, P. J. (1991). Issues of reliability and validity. In J. M. Morse (Ed.), Qualitative nursing research: A contemporary dialogue (pp. 164-186). Newbury Park, CA: Sage.

Boyd, C. O. (2001). Philosophical foundations of qualitative research. In P. E. Munhall (Ed). Nursing Research: A Qualitative Perspective (Third Edition). (s. 65-90). Boston, MA: NLN Press.

Carr, W., \& Kemmis, S. (2003). Becoming critical: education knowledge and action research. New York, NY: Routledge.

Cho, J., \& Trent, A. (2006). Validity in qualitative research revisited. Qualitative Research, 6(3), 319-340. https://doi.org/10.1177/1468794106065006 
Cramer, E., Liston, A., Nevin, A., \& Thousand, J. (2010). Co-Teaching in Urban Secondary School Districts to Meet the Needs of All Teachers and Learners:" Implications for Teacher Education Reform". International Journal of Whole Schooling, 6(2), 59-76.

Cressey, D. R. (1953). Other people's money; a study of the social psychology of embezzlement. New York, NY, US: Free Press

Creswell, J. W., \& Miller, D. L. (2000). Determining validity in qualitative inquiry. Theory into practice, 39(3), 124-130.

Creswell, J. W. (2007). Qualitative Inquiry and Research Design: Choosing Among Five Approaches. Thousands Oaks, CA: SAGE Publications, Inc.

Creswell, J. W. (2009). Research Design: Qualitative, Quantitative and Mixed Methods Approaches. Thousands Oaks, CA: SAGE Publications, Inc.

Denzin, N. K. \& Lincoln, Y. S. (2005). Introduction: The Discipline and Practice of Qualitative Research. In. N. K. Denzin ve Y. S. Lincoln (Ed.). The Sage Handbook of Qualitative Research ( $\left.3^{\text {rd }}\right)$. (s. 1-32). Thousands Oaks, CA: SAGE Publications, Inc.

Denzin, N. K., Lincoln, Y. S., \& Giardina, M. D. (2006). Disciplining qualitative research .International Journal of Qualitative Studies in Education, 19(6), 769-782.

Dilthey, W., \& Betanzos, R. J. (1923/1988). Introduction to the human sciences: An attempt to lay a foundation for the study of society and history. Detroit, MI: Wayne State University Press.

Durkheim, E. (1985). Toplumbilimsel yöntemin kuralları (Çev. C. B. Akal). İstanbul: BFS Yayınları.

Eisenhart, M. A., \& Howe, K. R. (1992). Validity in educational research. In M. LeCompte, W. Millroy, \& J. Preissle (Eds.), The Handbook of Qualitative Research in Education. (pp. 642-680). San Diego: Academic Press. 
Engels, F. (1996). Ludwig Feurebach and the Outcome of Classical German Philosophy. New York, NY: International Publishers.

Estabrooks, C. A., Field, P. A., \& Morse, J. M. (1994). Aggregating qualitative findings: an approach to theory development. Qualitative Health Research, 4(4), 503-511.

Fidan, T., \& Öztürk, İ. (2015). Perspectives and expectations of union member and non-union member teachers on teacher unions. Journal of Educational Sciences Research, 5(2), 191-220.

Geertz, C. (2005). Deep play: Notes on the Balinese cockfight. Daedalus, 134(4), 56-86.

Glesne, C. (2011). Becoming qualitative researchers: An introduction. (4 ${ }^{\text {th }}$ ed.).Boston,MA: Pearson.

Grbich, C. (2007). Qualitative Data Analysis: An Introduction. Thousands Oaks, CA: SAGE Publications, Inc.

Guba, E. G. (1981). Criteria for assessing the trustworthiness of naturalistic inquiries. Educational Technology research and development, 29(2), 75-91.

Guba, E. G., \& Lincoln, Y. S. (1981). Effective evaluation: Improving the usefulness of evaluation results through responsive and naturalistic approaches. San Fransisco, CA: Jossey-Bass.

Guba, E. G., \& Lincoln, Y. S. (1994). Competing paradigms in qualitative research. In N. K. Denzin ve Y. S. Lincoln (Ed.). Handbook of Qualitative Research (s. 105-117). Thousands Oaks, CA: SAGE Publications, Inc.

Guba, E. G., \& Lincoln, Y. S. (2005). Paradigmatic controversies, contradictions and emerging confluences. In. N. K. Denzin ve Y. S. Lincoln (Ed.). The Sage Handbook of Qualitative Research (Third Edition). (s. 191-216). Thousands Oaks, CA: SAGE Publications, Inc.

Hammersley, M. (2007). The issue of quality in qualitative research. International Journal of 
Research \& Method in Education, 30, 287-305.

Hammersley, M., \& Atkinson, P. (2007). Ethnography: Principles in practice ( $3^{\text {rd }}$.ed). London, UK: Routledge.

Kant, I. (1787/1998). Critique of Pure Reason (Trans. P. Guyer \& A. W. Wood). Riga: Johann Friedrich Hartknoch.

Kincheloe, J. L., \& McLaren, P. (2002). Rethinking critical theory and qualitative research. In Y. Zou and E. T. Trueba (Eds.). Ethnography and Schools: Qualitative Approaches to the Study of Education. (s. 87-138). Lanham, MD: Rowman \& Littlefield Publishers, Inc.

Knafl, K. A., \& Howard, M. J. (1984). Interpreting and reporting qualitative research. Research in Nursing \& Health, 7(1), 17-24.

Lather, P. (1993). Fertile obsession: Validity after poststructuralism. The sociological quarterly, 34(4), 673-693.

Lam, K. K., \& Hung, S. Y. M. (2013). Perceptions of emergency nurses during the human swine influenza outbreak: a qualitative study. International emergency nursing, 21(4), 240246.

Leininger, M. (1994). Evaluation criteria and critique of qualitative research studies. In J. M. Morse (Ed.). Critical Issues in Qualitative Research Methods. (s. 95-115). Thousand Oaks, CA: SAGE Publications, Inc.

Lewis, J. (2009). Redefining qualitative methods: Believability in the fifth moment. International Journal of Qualitative Methods, 8, 1-14.

Lincoln, Y. S., \& Guba, E. G. (1985). Naturalistic inquiry. Newbury Park, CA: Sage Publications. 
Lincoln, Y. S., \& Guba, E. G. (1986). But is it rigorous? Trustworthiness and authenticity in naturalistic evaluation. New directions for evaluation, (30), 73-84.

Liston, A. (2004). A qualitative study of secondary co-teachers. Orange, CA: Argosy University.

Marshall, M. N. (1996). Sampling for qualitative research. Family practice, 13(6), 522-526.

Marshall, C., \& Rossman, G. B. (2006). Designing qualitative research. Thousands Oaks. CA: SAGE Publications, Inc.

Maxwell, J. (1992). Understanding and validity in qualitative research. Harvard educational review, 62(3), 279-301.

Merriam, S. B. (2009). Qualitative Research: a guide to design and interpretation. San Francisco: Jossey-Bass.

Merriam, S. B., \& Tisdell, E. J. (2015). Qualitative Research: A Guide to Design and Implementation (Fourth Edition). San Fransisco, CA: Jossey Bass.

Miles, M. B., \& Huberman, A. M. (1994). An Expanded Sourcebook: Qualitative Data Analysis (Second edition). Thousand Oaks, CA: SAGE Publications, Inc.

Morrow, S. L. (2005). Quality and trustworthiness in qualitative research in counseling psychology. Journal of counseling psychology, 52(2), 250-260.

Morse, J. M. (1996). The purpose of qualitative research. In J. M. Morse ve P. A. Field (Ed.). Nursing Research: The Application of Qualitative Approaches. (s. 1-18). Falmouth, Cornwall: Chapman \& Hall.

Ormston, R., Spencer, L., Barnard, M. \& Snape, D. (2014) The foundations of qualitative research. In J. Ritchie, J. Lewis, C. M. Nicholls \& R. Ormston, (Eds.). Qualitative Research Practice: A Guide For Social Science Students And Researchers. (s. 1-26). Thousands Oaks, CA: SAGE Publications, Inc. 
Özdemir, M. (2010). Nitel veri analizi: Sosyal bilimlerde yöntembilim sorunsalı üzerine bir çalışma. Eskişehir Osmangazi Üniversitesi Sosyal Bilimler Dergisi, 11(1), 323-343.

Patton, M. Q. (2002). Qualitative research and evaluation methods (3rd ed). Thousand Oaks, CA: Sage Publications.

Ponterotto, J. G. (2005). Qualitative research in counseling psychology: A primer on research paradigms and philosophy of science. Journal of counseling psychology, 52(2), 126136.

Popper, K. (2002). Conjectures and refutations: The growth of scientific knowledge. New York, NY: Routledge.

Ray, M. A. (1994). The richness of phenomenology: Philosophic, theorethic and methodologic concerns. In Morse, J. M. (Ed.). Critical Issues in Qualitative Research Methods. (s. 117-133). Thousand Oaks, CA: SAGE Publications, Inc.

Roulston, K. (2010). Considering quality in qualitative interviewing. Qualitative Research, 10(2), 199-228.

Rüzgar, M.E. (2016).Eğitim Bilimlerine Uygun Yöntem Sorunu: Nitel Araştırma ve Erkuş’a Cevap. Illkögretim Online. 15 (4), 1-19.

Sandelowski, M. (1986). The problem of rigor in qualitative research. Advances in nursing science, $8(3), 27-37$.

Sandelowski, M., \& Barroso, J. (2002). Reading qualitative studies. International Journal of Qualitative Methods, 1, (1), 74-108.

Seale, C. (1999). Quality in qualitative research. Qualitative inquiry, 5(4), 465-478.

Sever, M. (2012). A Critical look at the theories of sociology of education. Journal of Human Sciences, 9(1), 650-671.

Sever, M., Soğuksu, A. F., Türe, E., Koçmar, Y., Olğun, M., Üçüncü, N., \& Öztürk, İ. (2016). What Does It Mean To Be a Student in Different Types of High Schools in Turkey 
YYÜ Eğitim Fakültesi Dergisi (YYU Journal of Education Faculty), 2018; 15(1):37-75, http://efdergi.yyu.edu.tr

through the Eyes of Students?. Educational Sciences: Theory \& Practice, 16(1), 231259.

Sharts-Engel, N. (1989). An American experience of pregnancy and childbirth in Japan. Birth, 16(2), 81-86.

Shenton, A. K. (2004). Strategies for ensuring trustworthiness in qualitative research projects. Education for information, 22(2), 63-75.

Shipman, S. D. (2015). The Role of Self-awareness in Developing Global Competence: A Qualitative Multi-case Study. Graduate Theses, Dissertations, and Capstones. Paper 21.

Silverman, D. (2000). Doing Qualitative Research: A Practical Handbook. Thousand Oaks, CA: Sage Publications, Inc.

Silverman, D. (2006). Interpreting qualitative data $\left(3^{\text {rd }}\right.$. ed). Thousand Oaks, CA: Sage Publications.

Silverman, D., \& Marvasti, A. (2008). Doing qualitative research: A comprehensive guide. Thousand Oaks, CA: Sage Publications.

Smith, J. K. (1984). The problem of criteria for judging interpretive inquiry. Educational evaluation and policy analysis, 6(4), 379-391.

Smith, J. K. (1990). Alternative research paradigms and the problem of criteria. In E. G. Guba (Ed.), The paradigm dialog (pp. 167-187). Newbury Park, CA: Sage Publications.

Sobo, E. J., Seid, M., \& Gelhard, L. R. (2006). Parent-Identified Barriers to Pediatric Health Care: A Process-Oriented Model. Health services research, 41(1), 148-172.

Stake, R. (2005). Qualitative case studies. In. N. K. Denzin ve Y. S. Lincoln (Ed.). The Sage Handbook of Qualitative Research (3 ${ }^{\text {rd }}$ Edition). (s. 443-466). Thousands Oaks, CA: SAGE Publications, Inc. 
Sultana, F. (2007). Reflexivity, positionality and participatory ethics: Negotiating fieldwork dilemmas in international research. ACME: An International Journal for Critical Geographies. 6(3), 374-385.

Thomas, N. P., \& Nyce, J. M. (1998). Qualitative research in LIS: Redux: A response to a [re] turn to positivistic ethnography. The Library Quarterly, 68(1), 108-113.

Thorne, S. (1997). The art (and science) of critiquing qualitative research. In J. M. Morse (Ed.). Completing a qualitative project: Details and dialogue (s. 117-132). Thousand Oaks, CA: SAGE Publications, Inc.

Weber, M. (1978). Economy and Society: An Interpretive Sociology (Edited by G. Roth and C. Wittich). Berkeley, CA: University of California Press.

Whittemore, R., Chase, S. K., \& Mandle, C. L. (2001). Validity in qualitative research. Qualitative health research, 11(4), 522-537.

Wynd, C. A., Schmidt, B., \& Schaefer, M. A. (2003). Two quantitative approaches for estimating content validity. Western Journal of Nursing Research, 25(5), 508-518.

Yıldırım, K. (2010). Nitel araştırmada niteliği arttırma. İlköğretim Online. 9 (1), 79-92.

Yin, R. K. (2009). Case Study Research: Design and Methods (Fourth Edition). Thousand Oaks, CA: SAGE Publications, Inc.

\section{EXTENDED ABSTRACT}

\section{Introduction}

Concepts such as positivism, optimism, reason and continuous progress have turned into dominant discourses with the "Age of Enlightenment" that emerged in the 18th century Europe. In this period, when all the information is believed to be accessible through reasoning, it is thought that the rational person has the ability to make implicit reality with meticulous reasoning. According to the contemporary philosophers of the Enlightenment, scientific 
knowledge, ignorance, and superstition reached by the processing of the observational data by logical processes had the potential to overcome it altogether. In other words, for positivism reality is absolute, not differentiated by persons. Realistic descriptions, clear aims, quantitative results measured properly, features such as neutrality and emphasis on objectivity, facts and theoretical tests that distinguish values from each other, are unique qualities that distinguish scientific research from other systematic thought forms. Quantitative methods have turned into natural gold standards for social sciences after the natural sciences.

However, as the problems of how people perceive their social and cultural experiences and their surroundings have come to the forefront, interest in qualitative research has begun. Qualitative research methods have begun to be used in social sciences, along with the diversity of the dynamics in contemporary life, the increase of disadvantaged groups in each area, differentiated life experiences and changing social relations. In short, the reaction of the society to the results of quantitative research has been influential in the forefront of qualitative research.

Both qualitative methods are frequently used in social research, and in recent times resources provided to qualitative researchers have increased there has been considerable debate about how to maintain quality in research and concerns about the issue are also increasing. At the beginning of the 20th century, social scientists had a consensus on what was regarded as evidence in science and revealed what kind of information would be valid. The idea that began in the 1970s as a qualitative research reform movement suggested that certain concepts of social and personal reality would not be possible through the finding and validation of positivist tradition. Lincoln and Guba initiated this debate by asking how the researcher should persuade his readers that the research findings are noteworthy. Since then, it has been seen that qualitative researchers have gained a significant understanding of this issue and that a large number of researches have been developed criteria for the quality of qualitative research. In these researches, the idea that qualitative researchers should show the results of research as valid and 
reliable appears to be at the forefront. It is important to conduct a quality research in order to ensure that the research is scientifically acceptable and feasible for use. However, developing a benchmark on validity and reliability is one of the most difficult and important problems facing social and educational research. In addition to efforts to develop specific criteria for qualitative research, some authors have completely rejected pre-determined criteria for qualitative research.

\section{Purpose}

In the light of these discussions, it is expected that this work, which is modeled in the conceptual survey model, will contribute to the field of validity and reliability in qualitative research and provide the basis for future discussions on the subject. In this context, unlike the limited number of studies in the literature, it is necessary to evaluate the efforts to develop criteria for the concepts of validity and reliability, which are controversial issues in the qualitative research tradition, and to arrive at a synthesis by going out of these opinions.

The aim of this study is to evaluate the discussions about the validity and reliability criteria which are frequently discussed in the qualitative research tradition. For this purpose, the views of philosophy schools which are based on different validity and reliability conceptualizations used in qualitative researches were discussed and the validity and reliability criteria of the most accepted social fictionalist-commentator in literature were examined.

\section{Ensuring quality in qualitative study}

Qualitative research methodology is criticized for its high objectivity and low reliability and validity. For example, there is criticism that there is no general system of qualitative research, and that it produces findings depending on a particular researcher. These criticisms are often based on the low quality of documentation and reporting of findings. It can be said that this criticism of qualitative research, which provides a holistic view of phenomena that it is difficult to obtain information is unfair. As a matter of fact, qualitative research methods 
mean the meaning and experience dimensions of human life and social world. In other words, the nature of qualitative research methods is not based on statistical or empirical calculations. Lincoln and Guba assert (1986) that describing quality enhancing criteria and techniques on the basis of the concept of trustworthiness can lift the conceptual complexity that often falls into the qualitative researchers.

\subsection{Trustworthiness}

The credibility, transferability, dependability and confirmability criteria provide the trustworthiness of a research. Transferability relates to the extent to which findings can be adapted to other contexts. Dependability means reaching the same findings with the same participants in the same context. Confirmability is to demonstrate that the findings are rooted not in the researcher but in the participants' experiences and considerations. According to Guba (1981), trustworthiness of qualitative research depends on the reflection of the value of the reality, the elimination of concerns about practicality, consistency and neutrality.

\section{Discussion and Conclusion}

Measuring quality in qualitative research seems to be a controversial issue, but it is not possible to establish a definite qualifying criterion in qualitative research. It seems that the effort to persuade the reader about the legitimacy of researching, in other words, the reflection and fairness of the different realities in the participants' minds, is at the center of the discussions of validity and reliability. The flexible and dynamic nature of qualitative research and the changes in different paradigms that guide qualitative research over time have led to the development of different validity and reliability measures. Nevertheless, this should not lead to a skeptical approach to the validity and reliability of qualitative research results. An epistemological argument that accurate information cannot be obtained from different mental realities, even if it can be reached, can lead to devaluation of legitimate methods and criterion-building efforts that qualitative researchers have undertaken in the face of congestion in quantitative research. 